\title{
Protein stability and functional activity during nebulization: A comparative study of three nebulizer!
}

Niti Singh ${ }^{1}$, Preeti Yadav ${ }^{1}$, Prekcha Gaur ${ }^{1}$, Manish Gaur ${ }^{1}$ and Awadh Bihari Yadav ${ }^{1, *}$

${ }^{1}$ Centre of Biotechnology, Allahabad University, Prayagraj-211002

*Corresponding author at: Centre of Biotechnology, Allahabad University, Pryagraj211002, India.

Email: awadh.dicau@gmail.com 


\begin{abstract}
Delivery of therapeutics protein to the lung offers effective treatments of lungs disease. Efficacy of delivered therapeutics molecules depends on integrity and stability of protein during nebulization. In this study, we compared three nebulizers: compressed air nebulizer (CAN), ultrasonic nebulizer (USN) and mesh nebulizer (MAN) to deliver aerosol dose, stability and functional activity of a model protein lysozyme. Lysozyme/BSA delivered dose assessed by indirect and direct method. It was shown CAN deliver $0.142 \pm 0.027$ to $0.632 \pm 0.09 \mathrm{ml}$ of protein, USN deliver $0.511 \pm 0.119$ to $1.688 \pm 0.173 \mathrm{ml}$ and MAN deliver $0.238 \pm 0.006$ to $0.731 \pm 0.013 \mathrm{ml}$ of protein in the same time. Integrity of nebulized proteins were assessed by gel electrophoresis and circular diochorism. It was found integrity of lysozyme compromised in all three nebulizer maximum in CAN and minimum with MAN. The functional activity of protein was assessed after nebulization by turbidometry assay. The functional activity was compromised by all three nebulizer upto some extent. In conclusion, nebulization compromise protein stability: this impact depend on nebulization techniques as well as nature of protein. The CAN deliver protein more precisely in small amount in comparison to the other nebulizer.
\end{abstract}

Keywords: Compressed air nebulizer; Ultrasonic nebulizer; Mesh Nebulizer; Circular Diochroism; Protein stability; Lysozyme Turbidity assay; 


\section{Introduction}

Lung diseases are the most common diseases, which includes asthma, chronic obstructive pulmonary disease (COPD), Cystis fibrosis, tuberculosis and lung cancer, spread worldwide [1]. Lung disease associated pathologies includes inflamed airways, allergies, infections, long term wet cough and other condition which ultimately compromise the healthy functioning of a lung [2]. Main causes of the lung disease are smoking, infections and pollution, which lead to the damage of the lung surface. According to WHO report, 235 million people is suffering from asthma worldwide and $30 \%$ of Indian population suffers from lung disease $[3,4]$. At present, different treatments used for the treatment of Asthma \& lung inflammation are delivered thorough the inhalation route [5]. Inhalation route offer advantages on conventional route and provide quick relief from the life threatening condition developed in asthma and other diseases by delivering quick therapeutics molecules on the lung surface $[6$, 7]. In asthma and lung inflammation steroid based therapeutics are in used which compromise immune system and add more side effect [8]. Protein/peptide based therapeutics molecules offers advantages over steroid based therapy to not interfere with host immune system, target specific activity and less side effect in comparison to other therapy $[9,10]$.

Therapy based on protein/peptide limited by their stability \& integrity to deliver at the site of disease. Several therapeutic proteins/peptides under different developmental stage for the treatment of lungs disease by nebulization method [11]. The human deoxyribonuclease I and dornase- $\alpha$ are used for the treatment of cystic fibrosis and lung infections respectively $[12,13]$, nebulized recombinant secretory leukocyte protease inhibitor (rSLPI) show good activity in lung inflammation site and has been 
proposed for the treatment of asthma [14]. A. Artigas et.al. demonstrated that nebulized heparin control pulmonary inflammation through macrophage in rat lung Injury model [15]. Acute lung injury and pulmonary inflammation can be reduced by aerosolized indomethacin in to a rat animal model [16]. Other groups demonstrated that aerosolized pulmonary surfactant inhaling can reduce proinflamatory cytokines in bronchoalveolar lavage fluid (BALF) [17]. Y. Chen et.al. reported that nebulized mycobacterium vaccine can protect against asthma in mice [18]. Nebulized anticoagulants can also attenuate lung inflammation [19].

Efficacy of therapeutics molecules depends on many factors, such as stability, integrity of molecules during and after nebulization. High-frequency acoustic waves based nebulizer delivered $70 \%$ size range of peptide for deep lung delivery without any compromise in their integrity [20]. A nebulizer based on acoustomicrofluidic capable to nebulized epidermal growth factor receptor (EGFR) into fine aerosol of mass median aerodynamic diameter of approximately $1.1 \square \mu \mathrm{m}$ with no significant degradation observed after nebulization [21]. In inhaled therapy it's very critical and essential to preserve stability and integrity of formulation during nebulization [22].

The aim of this study was try to find out which nebulizer able to deliver protein/peptide without or minimum compromise their stability during nebulization. At present nebulizer are used based on three principles: compressed air nebulizer, ultrasonic vibration \& mesh nebulizer. Furthermore all three nebulizer was analyzed for dose delivered as output dose, stability, integrity and functional activity of nebulized protein. 


\section{Materials and Methods:}

\subsection{Materials}

Bovine Serum albumin (BSA), Lysozyme, Micrococcus luteus, Tween-20 and all electrophoresis reagents from from Sigma, Banglore, India, Phosphate Buffer Saline

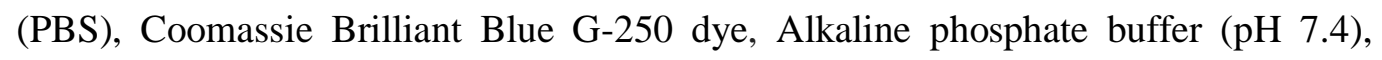
TrisHCl buffer, Acetic acid and Ethanol from Hi Media, India, Molecular Weight marker 10-250 kDa (Fermentas) and Glycerol, Methanol (Molychem).

\subsection{Methods}

\subsubsection{Nebulization and metered dose delivery}

In this study we used three different nebulizers: Compressor air nebulizer (CAN), ultrasonic nebulizer (USN) and mesh nebulizer (MAN) to deliver lysozyme or BSA as model molecules.

CAN (NE-C28, Omron Healthcare Co., Ltd) works between the temperatures range $10{ }^{\circ} \mathrm{C}-40{ }^{\circ} \mathrm{C}$ and is capable of generating a particle size of $\sim 3 \mu \mathrm{m}$, with aerosol output rate of $0.06 \mathrm{ml} / \mathrm{min}$, and a nebulization rate of $0.4 \mathrm{ml} / \mathrm{min}$ with sample reservoir between 2-7 ml. The Mass Median Aerodynamic Diameter (MMAD) of generated particles was $3 \mu \mathrm{m}$.

USN (BD5200, BremedTodi (PG)-Italy) works between the temperature range $10^{\circ} \mathrm{C}$ - $40{ }^{\circ} \mathrm{C}$. The sample reservoir volume for this nebulizer is $3 \mathrm{ml}$ and the average nebulization rate is $1 \mathrm{ml} / \mathrm{min}$. The particles generated by ultrasonic nebulizer fall between size ranges of 0.5 to $4 \mu \mathrm{m}$. 
Mess nebulizer (NE-U22, Omron Healthcare Co., Ltd) contains mesh/membrane with 1000-7000 laser drilled holes, which vibrates at the top of the sample reservoir due which a pressures out a mist of very fine droplets through the holes. The sample reservoir volume between $3 \mathrm{ml}-5 \mathrm{ml}$. The aerosol output rate is approx. $0.85 \mathrm{ml} / \mathrm{min}$. The average nebulizer flow rate is $0.429 \mathrm{ml} / \mathrm{min}$.

Metered dose delivered by the three different nebulizers at different time points was analyzed by indirect and direct method.

In the indirect method, the dose delivered was determined by subtracting final volume remain in reservoir with the initial sample volume after nebulization. In brief, $3 \mathrm{ml}$ of sample was taken into CAN, USN or MAN. Sample was nebulized for different time points: 30, 45, 60, 90, 120, 145 and 165 sec. After nebulization, delivered dose was calculated by subtracting the remaining volume of sample from initial volume of sample in reservoir. The same experiment was repeated for five times $(n=5)$.

In the direct method, the dose delivered was determined by measuring total protein in the collected volume after different time nebulization by measuring collected sample in $50 \mathrm{ml}$ falcon tube or measuring protein in collected sample by Bradford or Lorry method. In brief, $3 \mathrm{ml}$ of protein sample was taken into nebulizer and nebulized for different time point $30,45,60,90,120,145 \& 165.30 \mu$ of the nebulized was diluted to make $500 \mu \mathrm{l}$ in buffer and equal amount of Bradford reagent was added to quantified protein by measuring absorbance at $595 \mathrm{~nm}$ by UV-Visible spectrophotometer (Evolution 201, Thermo). The same experiment was repeated for three times $(n=3)$

\subsubsection{Stability of Nebulized Protein}




\subsubsection{Gel Electrophoresis}

Protein integrity after nebulization by CAN, USN or MAN nebulizers were studied by gel electrophoresis (10\% SDS PAGE). In brief, nebulized protein aerosols were collected at different time point and collected samples were loaded on poly acrylamide gel along with appropriate molecular weight marker. The electrophoresis was performed at standard condition and gel was stained with Coomassie Brilliant Blue R-250 dye.

\subsubsection{Circular Diochorism (CD) Spectroscopy}

Stability of lysozyme was studied after nebulization by CAN, USN \& MAN by circular diochorism (CD) spectroscopy. In brief nebulized lysozyme sample was collected at $60 \mathrm{sec}$. These collected sample was analyzed for their CD spectra between wavelength 190-270 nm in the equal amount of protein sample. This experiment was performed in triplicate to record CD spectra. Water and Buffer was taken as blank for this experiments.

\subsubsection{Lysozyme activity by turbidity assay}

The functional activity of lysozyme was assessed by measuring turbidity at different time points $30,45,60,90,120,145 \& 165 \mathrm{sec}$ of nebulized sample by three different nebulizer [23]. In brief, Lysozyme solution was prepared into $66 \mathrm{mM}$ potassium phosphate buffer ( $\mathrm{pH}$ 6.24) and micrococcus luteus $(0.015 \%(\mathrm{w} / \mathrm{v}))$ solution into the same buffer. $2.5 \mathrm{ml}$ of bacterial solution were transferred into a quartz cuvette and reference absorbance was read at $450 \mathrm{~nm} .100 \mu \mathrm{l}$ of lysozyme solution were added and mixed quickly and absorbance was recorded for 5 min at $25^{\circ} \mathrm{C}$ and each reaction 
was performed in triplicate. Enzyme activity into different sample was calculated by following equation mentioned below:

$$
\text { Enzyme }\left(\frac{\text { Units }}{m l}\right)=\frac{(\Delta \mathrm{A} 450 \mathrm{~nm} / \mathrm{min} \text { Test }-\Delta \mathrm{A} 450 \mathrm{~nm} / \min \text { Blank })(d f)}{\frac{\Delta \mathrm{A} 450 \mathrm{~nm}}{\text { unit }} \times v}
$$

Where $\mathrm{df}=$ Dilution factor

$\Delta \mathrm{A} 450 \mathrm{~nm} / \mathrm{unit}=$ Change in absorbance at A450nm/ per Unit of enzyme

$\mathrm{v}=$ Volume of enzyme (in milliliter) used in assay

\subsubsection{Statistical analysis of the results}

The significance levels of the results between groups were calculated by one-way Analysis of variance (ANOVA) which including post hoc testing by Tukey to calculate individual p-values. The symbols and significance levels displayed are listed in Table 1. 


\section{Results and Discussion}

\subsection{Metered dose delivered by different nebulizer}

The focus of this study was to establish dose of protein delivered by different nebulizers and to find out whether integrity of delivered protein was compromised during nebulization, which ultimately affect efficacy of protein. Therefore protein sample was nebulized for same time using all three nebulizer CAN, USN \& MAN. We use phosphate buffer for lysozyme study. A statistically significant data using statistical design to represented with sufficient number of replicate of experiments (Table 1).

The output volume of lysozyme/BSA was assessed by measuring nebulized volume of sample by indirect method. We observed correlation of output volume nebulized between $30 \mathrm{sec}$ to $165 \mathrm{sec}$ by CAN was $\mathrm{R}^{2}=0.99$, for $\mathrm{USN}^{2}=0.99$ and for MAN $\mathrm{R}^{2}$ $=0.99$ (Fig. 1A). We also assessed output dose collected into $50 \mathrm{ml}$ falcon tube by direct method at different time point between $30 \mathrm{sec}$ to $165 \mathrm{sec}$. Protein in collected sample was quantified by Lowry method. The correlation of output dose was found to be for $\mathrm{CAN} \mathrm{R}^{2}=0.98, \mathrm{USN} \mathrm{R}^{2}=0.99$ and MAN R ${ }^{2}=0.99$ (Fig. 2A).

The dose delivered assessed by indirect method was $0.142 \pm 0.027$ to $0.632 \pm 0.09 \mathrm{ml}$ CAN, $0.511 \pm 0.119$ to $1.688 \pm 0.173 \mathrm{ml} \mathrm{USN}$ and $0.238 \pm 0.006$ to $0.731 \pm 0.013 \mathrm{ml}$ MAN 30 to $165 \mathrm{sec}$ (Fig.1 B). The dose delivered also assessed by direct method was $0.318 \pm 0.061$ to $3.71 \pm 0.215 \mu \mathrm{g}$ CAN, $3.45 \pm 0.653$ to $11.02 \pm 0.553 \mu \mathrm{g}$ USN and $1.55 \pm 0.098$ to $4.88 \pm 0.079 \mu \mathrm{g}$ in 30 to $165 \mathrm{sec}$ (Fig.2 B). The compressed air nebulizer 
can deliver small dose of protein more precisely in comparison to USN and MAN. The dose delivered by different nebulizer was also assessed by direct method. Protein was estimated in sample collected at different time point after nebulization by CAN, USN \& MAN nebulizer by Bradford/lowery method. In this study it was shown USN and MAN can deliver large amount of protein in small time in comparison to CAN.

\section{Stability of protein:}

The impact of nebulization on protein integrity and stability was studied by gel electrophoresis and CD spectroscopy of sample nebulized by CAN, USN \& MAN nebulizer. This experiment were performed with a protein solution into a recommended strength and $\mathrm{pH}$ of buffer. Stability of nebulized proteins is very crucial for the efficacy of protein. Degradation of protein was observed in SDS PAGE following CAN, USN \& MAN nebulization (Fig. 3).

Near UV CD spectra provide information about the environment around aromatic group in a protein. Difference in the spectra (peak shifting) of a protein indicate that there is change into surrounding environment around aromatic group in a protein. Near UV CD spectra of lysozyme was assessed after nebulization of CAN, USN \& MAN (Fig. 4). Buffer and protein solution was used as reference sample. The sample nebulized by different nebulizer for $60 \mathrm{sec}$ was showing different amount of tertiary structure compromization: maximum compromised by CAN, USN and minimal structure compromised by MAN.

\section{Activity of Lysozyme}

The integrity and stability compromised during nebulization whether it affect lysozyme activity was investigated by turbidity assay. Lysozyme sample nebulized by 
CAN, USN \& MAN nebulizer for $60 \mathrm{sec}$. The lysozyme activity of nebulized sample were compared with native lysozyme solution without any nebulization (Fig. 5). Functional activity of lysozyme was also assessed in the sample after nebulization for different time (Data not shown).

During nebulization by CAN for 60 sec $82.6 \%$ lysozyme activity was lost, nebulization by USN 74.4\% and nebulization by MAN 33.2\% lysozyme activity was lost. There are different factor which attribute to the activity loss of lysozyme sample which includes heating, aggregation of protein and liquid air interface formation [24]. In CD spectra it was shown maximum structural loss was in sample nebulized by CAN (Fig.4). Activity loss of lysozyme during nebulization can be minimized by reducing temperature of sample reservoir during nebulization and to reduce interfacial stress by adding suitable excipient [24]. An appropriate combination excipient and temperature control required to achieve optimal protection and retain optimal functional activity of lysozyme during nebulization $[25,26]$.

\section{Discussion}

We studied the dose delivered by three different nebulizer in the same time and how it affect stability and activity of a protein during nebulization. It was found that dose delivered by compressed air nebulizer more precise in small amount in the same time dose delivered by ultrasonic and mesh nebulizer. All three nebulizer affect stability of protein sample during nebulization: maximum compromised by CAN, USN and minimum by MAN. These stability compromised due to many factor such as heat generation, air water interface formation \& fragmentation of therapeutic molecules during nebulization by different nebulizer. In 2015 W. Friess et. al. explain protein instability due to unfolding \& aggregation at the air-liquid interface [11]. They also 
demonstrated stability for protein vary and depend on the nature protein [27]. Stability of protein sample can be improved by minimizing heat generation during nebulization. It can be also improved by incorporating suitable excipient to protect samples exposure to air and surface interface which also responsible for denaturation of protein sample during nebulization. It observed that Tertiary structure of protein affected by nebulization. Different nebulizer affect different level of tertiary structure of a protein. Slight change in tertiary structure significantly affect activity of protein.

Protein stability compromised during nebulization is a bottle neck to use of this convenient administration method to deliver protein formulation into the lung for the treatments of many disease such as tuberculosis, lung inflammation, COPD, cystic fibrosis. During nebulization it was reported that formation of aggregates and degradation of protein affect efficacy of therapeutic protein [24, 28]. Ultrasonic nebulizer also affect protein efficacy around 50\% of activity loss was reported during nebulization of protein solution [29].

Conclusion of our study (i) compressed air nebulizer deliver small dose more precisely (ii) ultrasonic and mesh nebulizer delivered high amount in comparison to CAN. Protein nebulized by CAN, USN \& MAN nebulizers is prone for degradation. Protein nebulized by CAN show high degradation in comparison to the USN \& MAN. Maximum activity loss of lysozyme observed in compressed air nebulized sample, no or very less activity loss was observed in sample nebulized by mesh nebulizer.

\section{Author contributions:}

Funding Source: This work was supported by the Core Grant CRG/2018/002135 grant by Science and Engineering Research Board (SERB), DST, Government of India. 
Conflict of interest: There are no potential conflicts of interest to disclose for this work.

\section{Acknowledgment}

We are thankful to Science and Engineering Research Board (SERB) New Delhi, India for providing financial support for this project.

\section{References:}

[1] A. Navarro-Torne, M. Vidal, D.K. Trzaska, L. Passante, A. Crisafulli, H. Laang, J.W. van de Loo, K. Berkouk, R. Draghia-Akli, Chronic respiratory diseases and lung cancer research: a perspective from the European Union, The European respiratory journal, 46 (2015) 1270-1280.

[2] Y. Shen, S. Huang, J. Kang, J. Lin, K. Lai, Y. Sun, W. Xiao, L. Yang, W. Yao, S. Cai, K. Huang, F. Wen, Management of airway mucus hypersecretion in chronic airway inflammatory disease: Chinese expert consensus (English edition), International journal of chronic obstructive pulmonary disease, 13 (2018) 399-407.

[3] P. Kumar, U. Ram, Patterns, factors associated and morbidity burden of asthma in India, PloS one, 12 (2017) e0185938.

[4] G. Bishwajit, S. Tang, S. Yaya, Z. Feng, Burden of asthma, dyspnea, and chronic cough in South Asia, International journal of chronic obstructive pulmonary disease, 12 (2017) 1093-1099.

[5] A. Safdar, S.A. Shelburne, S.E. Evans, B.F. Dickey, Inhaled therapeutics for prevention and treatment of pneumonia, Expert opinion on drug safety, 8 (2009) 435449.

[6] J.S. Patil, S. Sarasija, Pulmonary drug delivery strategies: A concise, systematic review, Lung India : official organ of Indian Chest Society, 29 (2012) 44-49. 
[7] J.M. Borghardt, C. Kloft, A. Sharma, Inhaled Therapy in Respiratory Disease: The Complex Interplay of Pulmonary Kinetic Processes, Canadian respiratory journal, 2018 (2018) 2732017.

[8] J. Charriot, I. Vachier, L. Halimi, A.S. Gamez, C. Boissin, M. Salama, A. CucuJarjour, E. Ahmed, A. Bourdin, Future treatment for asthma, European respiratory review : an official journal of the European Respiratory Society, 25 (2016) 77-92.

[9] A.E. Coutinho, K.E. Chapman, The anti-inflammatory and immunosuppressive effects of glucocorticoids, recent developments and mechanistic insights, Molecular and cellular endocrinology, 335 (2011) 2-13.

[10] P.J. Barnes, New drugs for asthma, Nature reviews. Drug discovery, 3 (2004) $831-844$

[11] S.P. Hertel, G. Winter, W. Friess, Protein stability in pulmonary drug delivery via nebulization, Advanced drug delivery reviews, 93 (2015) 79-94.

[12] D. Cipolla, I. Gonda, S.J. Shire, Characterization of aerosols of human recombinant deoxyribonuclease I (rhDNase) generated by jet nebulizers, Pharmaceutical research, 11 (1994) 491-498.

[13] K.L. Goa, H. Lamb, Dornase alfa. A review of pharmacoeconomic and qualityof-life aspects of its use in cystic fibrosis, PharmacoEconomics, 12 (1997) 409-422.

[14] A. Gibbons, D. Padilla-Carlin, C. Kelly, A.J. Hickey, C. Taggart, N.G. McElvaney, S.A. Cryan, The effect of liposome encapsulation on the pharmacokinetics of recombinant secretory leukocyte protease inhibitor (rSLPI) therapy after local delivery to a guinea pig asthma model, Pharmaceutical research, 28 (2011) 2233-2245.

[15] L. Chimenti, M. Camprubi-Rimblas, R. Guillamat-Prats, M.N. Gomez, J. Tijero, L. Blanch, A. Artigas, Nebulized Heparin Attenuates Pulmonary Coagulopathy and 
Inflammation through Alveolar Macrophages in a Rat Model of Acute Lung Injury, Thrombosis and haemostasis, 117 (2017) 2125-2134.

[16] R.L. Kao, W. Huang, C.M. Martin, T. Rui, The effect of aerosolized indomethacin on lung inflammation and injury in a rat model of blunt chest trauma, Canadian journal of surgery. Journal canadien de chirurgie, 61 (2018) S208-S218.

[17] Y.M. Yan, Y.D. Li, X.L. Song, M. Liu, F. Diao, Y. Wang, Y. Sun, Z.H. Wang, J. Lu, Therapeutic effects of inhaling aerosolized surfactant alone or with dexamethasone generated by a novel noninvasive apparatus on acute lung injury in rats, The journal of trauma and acute care surgery, 73 (2012) 1114-1120.

[18] C. Li, X. Jiang, M. Luo, G. Feng, Q. Sun, Y. Chen, Mycobacterium vaccae Nebulization Can Protect against Asthma in Balb/c Mice by Regulating Th9 Expression, PloS one, 11 (2016) e0161164.

[19] P.R. Tuinman, B. Dixon, M. Levi, N.P. Juffermans, M.J. Schultz, Nebulized anticoagulants for acute lung injury - a systematic review of preclinical and clinical investigations, Critical care, 16 (2012) R70.

[20] Y. Wang, A.R. Rezk, J.S. Khara, L.Y. Yeo, P.L. Ee, Stability and efficacy of synthetic cationic antimicrobial peptides nebulized using high frequency acoustic waves, Biomicrofluidics, 10 (2016) 034115.

[21] C. Cortez-Jugo, A. Qi, A. Rajapaksa, J.R. Friend, L.Y. Yeo, Pulmonary monoclonal antibody delivery via a portable microfluidic nebulization platform, Biomicrofluidics, 9 (2015) 052603.

[22] J. Alkiewicz, A. Szczawinska-Poplonyk, M. Makowska, [Stability of inhaled drugs as a requisite for safe therapy as for example, with nebulised glucocorticosteroids], Pneumonologia i alergologia polska, 65 Suppl 1 (1997) 7-17. 
[23] T.B. Toro, T.P. Nguyen, T.J. Watt, An improved 96-well turbidity assay for T4 lysozyme activity, MethodsX, 2 (2015) 256-262.

[24] R. Respaud, D. Marchand, C. Parent, T. Pelat, P. Thullier, J.F. Tournamille, M.C. Viaud-Massuard, P. Diot, M. Si-Tahar, L. Vecellio, N. Heuze-Vourc'h, Effect of formulation on the stability and aerosol performance of a nebulized antibody, mAbs, 6 (2014) 1347-1355.

[25] W. Wang, Advanced protein formulations, Protein science : a publication of the Protein Society, 24 (2015) 1031-1039.

[26] M. Rohm, S. Carle, F. Maigler, J. Flamm, V. Kramer, C. Mavoungou, O. Schmid, K. Schindowski, A comprehensive screening platform for aerosolizable protein formulations for intranasal and pulmonary drug delivery, International journal of pharmaceutics, 532 (2017) 537-546.

[27] E. Bodier-Montagutelli, R. Respaud, G. Perret, L. Baptista, P. Duquenne, N. Heuze-Vourc'h, L. Vecellio, Protein stability during nebulization: mind the collection step!, European journal of pharmaceutics and biopharmaceutics : official journal of Arbeitsgemeinschaft fur Pharmazeutische Verfahrenstechnik e.V, (2020).

[28] S. Hengsawas Surasarang, G. Florova, A.A. Komissarov, S. Shetty, S. Idell, R.O. Williams, 3rd, Formulation for a novel inhaled peptide therapeutic for idiopathic pulmonary fibrosis, Drug development and industrial pharmacy, 44 (2018) 184-198. [29] S.H. Surasarang, S. Sahakijpijarn, G. Florova, A.A. Komissarov, C.L. Nelson, E. Perenlei, S. Fukuda, M.R. Wolfson, T.H. Shaffer, S. Idell, R.O. Williams, 3rd, Nebulization of Single-Chain Tissue-Type and Single-Chain Urokinase Plasminogen Activator for Treatment of Inhalational Smoke-Induced Acute Lung Injury, Journal of drug delivery science and technology, 48 (2018) 19-27. 


\section{Table 1}

Significance levels and symbols to indicate them throughout this study.

\begin{tabular}{lc}
\hline Symbol & Meaning \\
\hline Ns & $\mathrm{P}>0.05$ \\
$*$ & $\mathrm{P} \leq 0.05$ \\
$* *$ & $\mathrm{P} \leq 0.01$ \\
$* * *$ & $\mathrm{P} \leq 0.001$ \\
\hline
\end{tabular}




\section{Figure}

A
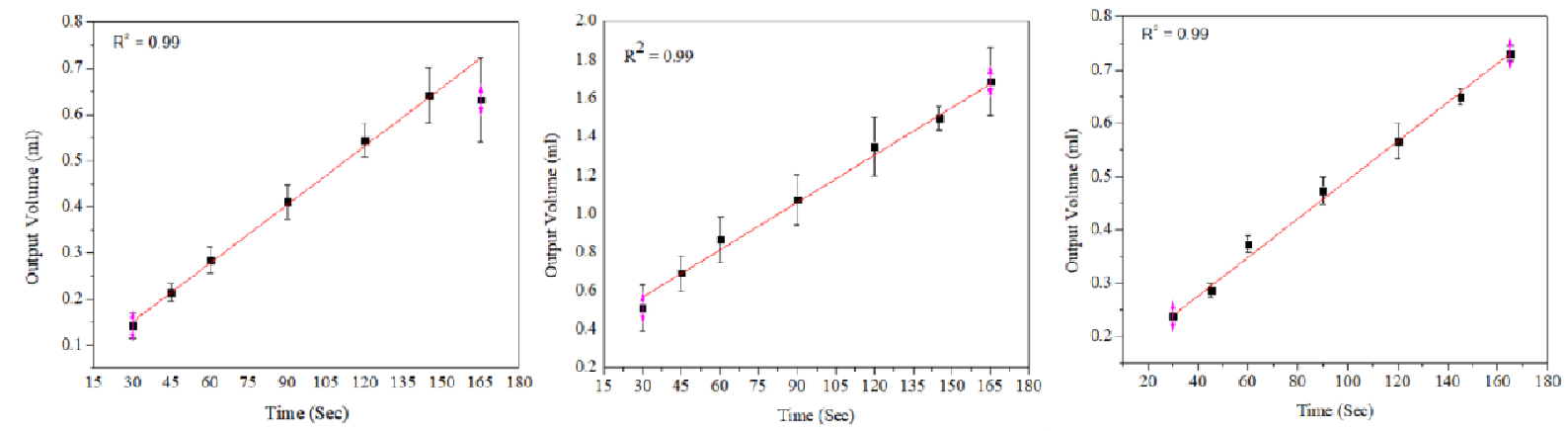

B

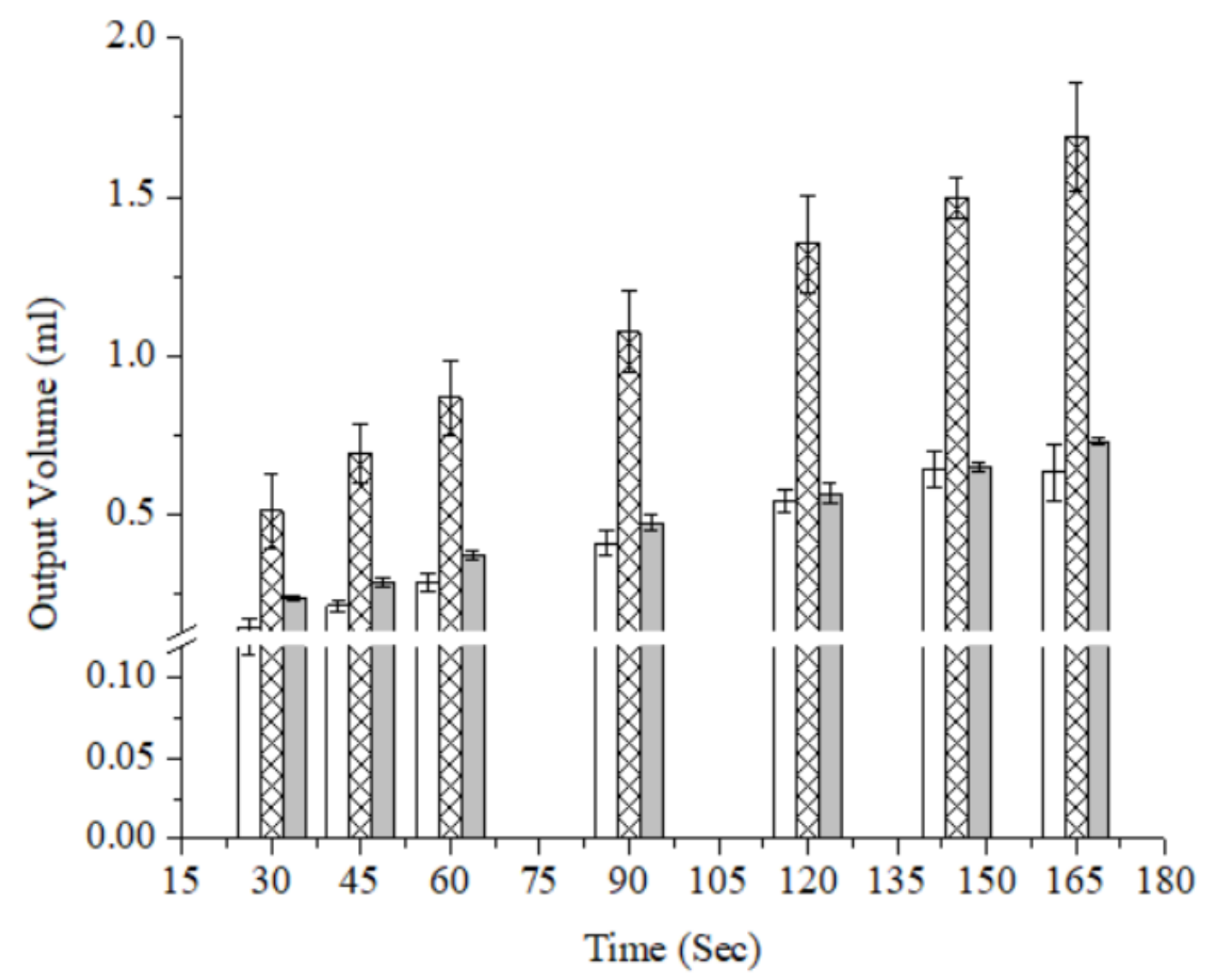

Fig. 1. (A) Correlation of output volume with reference to time of nebulized protein by CAN $\left(\mathrm{R}^{2}=0.99\right)$, USN $\left(\mathrm{R}^{2}=0.99\right)$ and MAN $\left(\mathrm{R}^{2}=0.99\right)$.(B) Dose delivered by CAN (hollow bar), MSN (cross line bar) and MAN (light gray bar) after nebulization and analyzed by indirect method, $n=5$ (mean $\pm S D)$. 
A
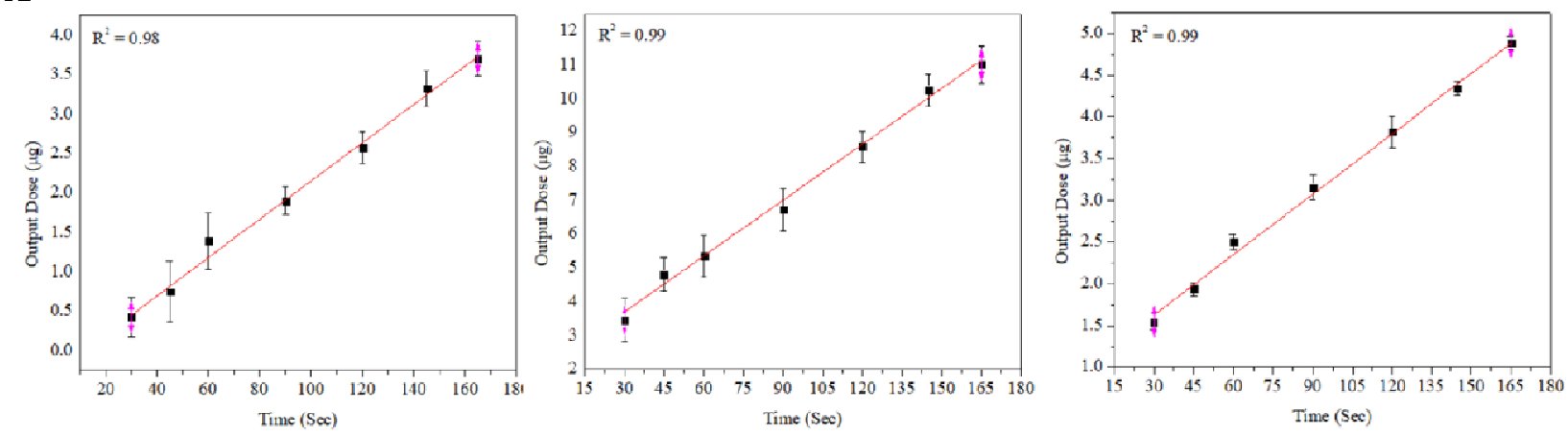

$\mathbf{B}$

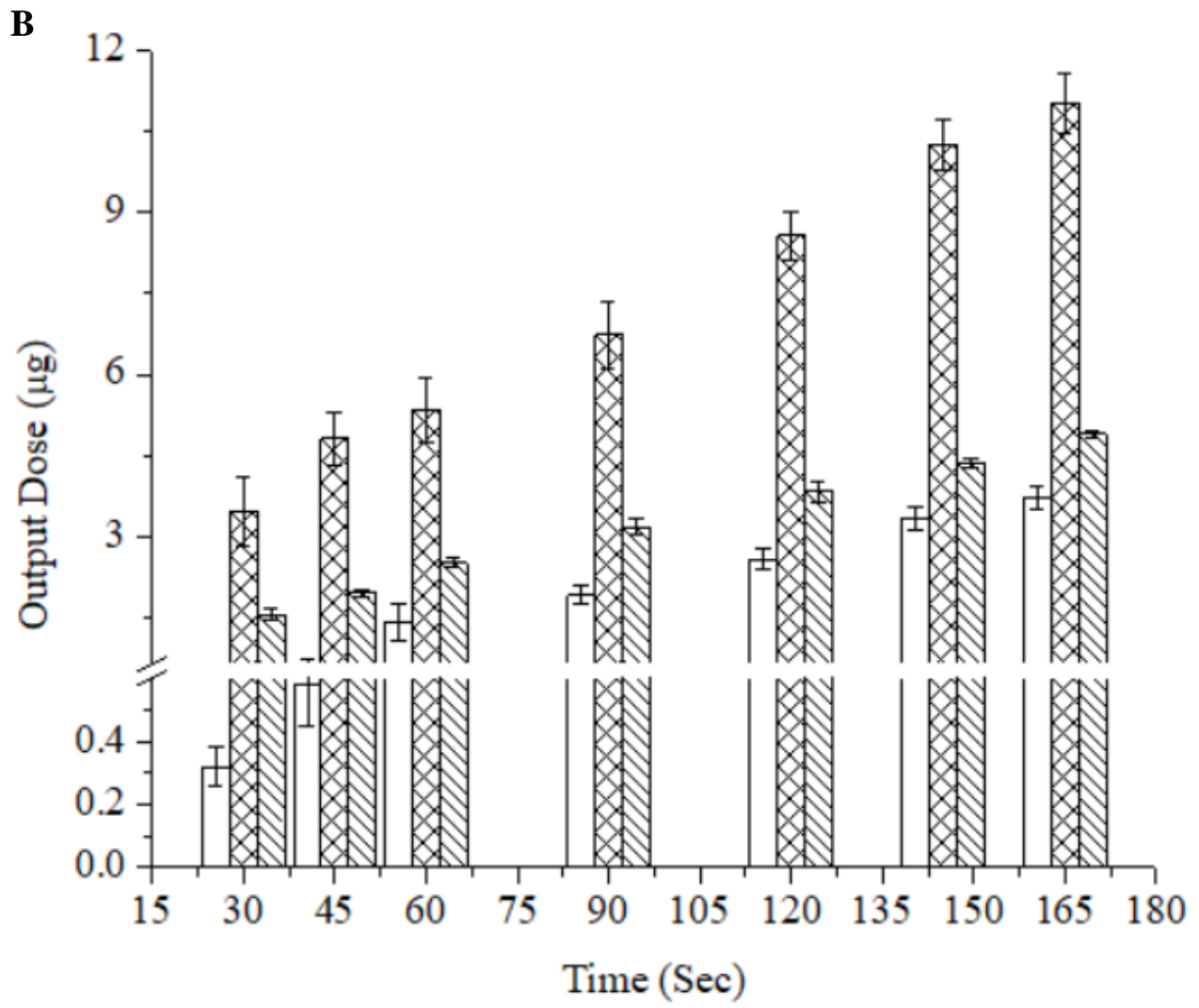

Fig.2. (A) Correlation of output dose with reference to time of nebulized protein by CAN $\left(\mathrm{R}^{2}=0.98\right)$, USN $\left(\mathrm{R}^{2}=0.99\right)$ and MAN $\left(\mathrm{R}^{2}=0.99\right)$. (B) Dose delivered by CAN (hollow bar), MSN (cross bar) and MAN (cross section bar) diagram at different time point by direct method, $\mathrm{n}=5$ (mean $\pm \mathrm{SD})$. 


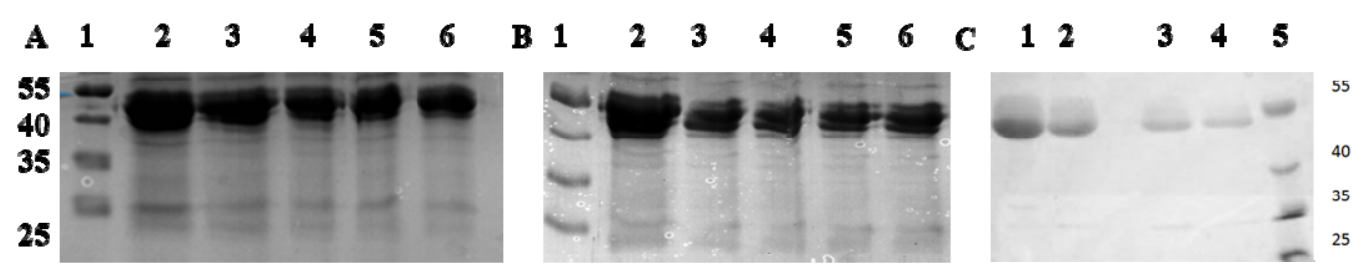

Fig. 3. SDS PAGE analysis of sample after nebulization for different time point

by (A) MAN lane 1 molecular weight marker (fermentas, SM1811), lane 2 native protein, lane 3-6 protein in different time interval (45 sec, $120 \mathrm{sec} 165 \mathrm{sec}, 195 \mathrm{sec}$ ), (B) by UAN lane 1 molecular wieight marker, lane 2 native protein lane 3-6 protein in different time interval (45 sec, $120 \mathrm{sec} 165 \mathrm{sec}, 195 \mathrm{sec}$ ) ( C) by CAN lane 5 molecular wieight marker, Lane 4 native protein Lane 3, 2 and 1 protein sample nebulized for different time point $(5,7 \& 9 \mathrm{~min})$. 


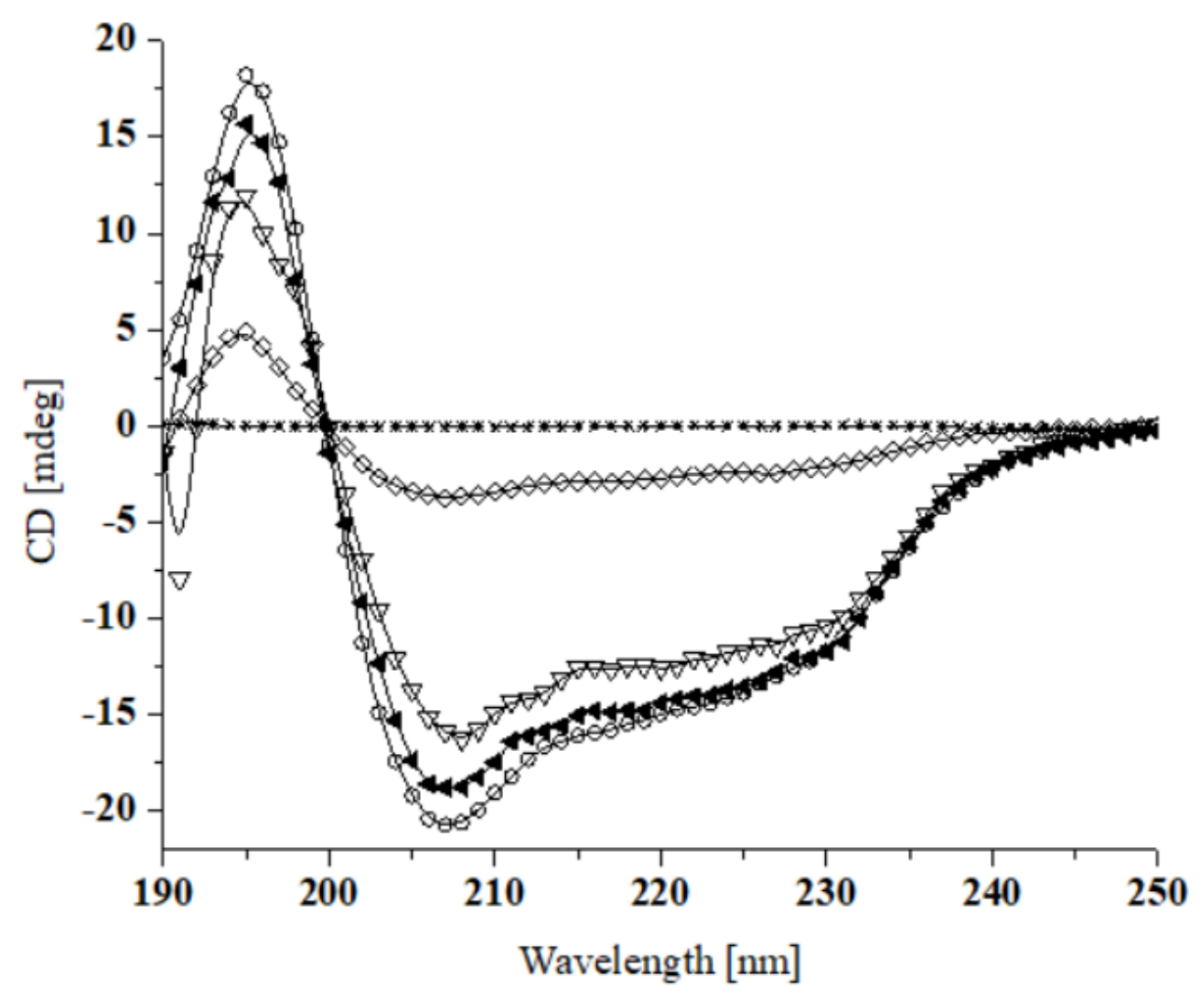

Fig. 4. CD spectra of nebulized buffer (-*-), CAN (-目), USN (- $\left.-^{-}\right)$, MAN (- $\left.\boldsymbol{\Delta}_{-}^{-}\right)$ and Native (-०-) of lysozyme sample for $60 \mathrm{sec}$ and spectra recorded at near UV region 190-270 $\mathrm{nm}$ of $100 \mathrm{ug}$ of protein in each sample $\mathrm{n}=3$ (mean $\pm \mathrm{SD})$. 


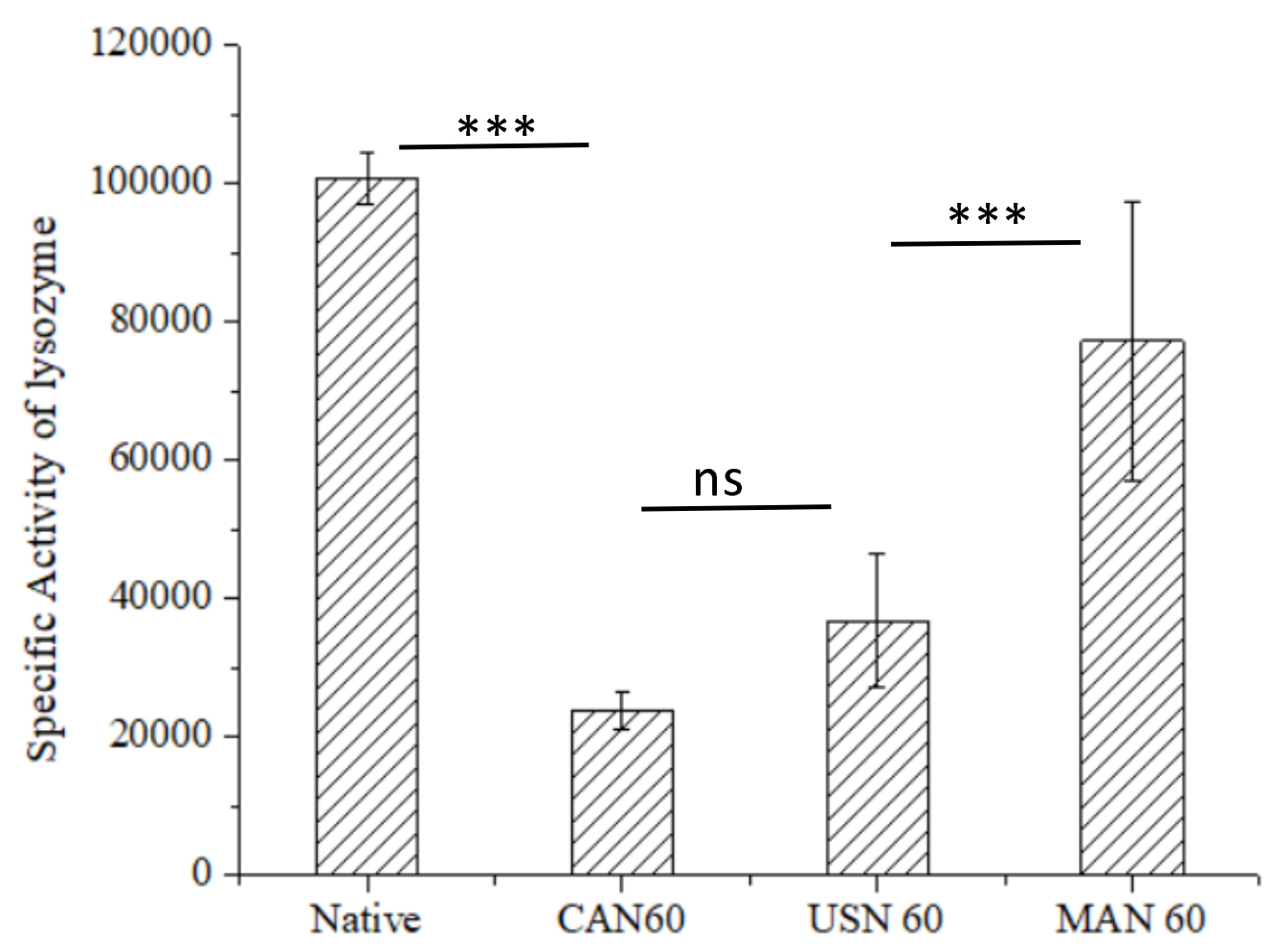

Fig.5. Lysozyme activity in nebulized aerosol sample collected for $60 \mathrm{sec}$ by CAN, USN or MAN nebulizer by turbidometry assay, $\mathrm{n}=5$ (mean $\pm \mathrm{SD})$. 


\section{Graphical Abstract}

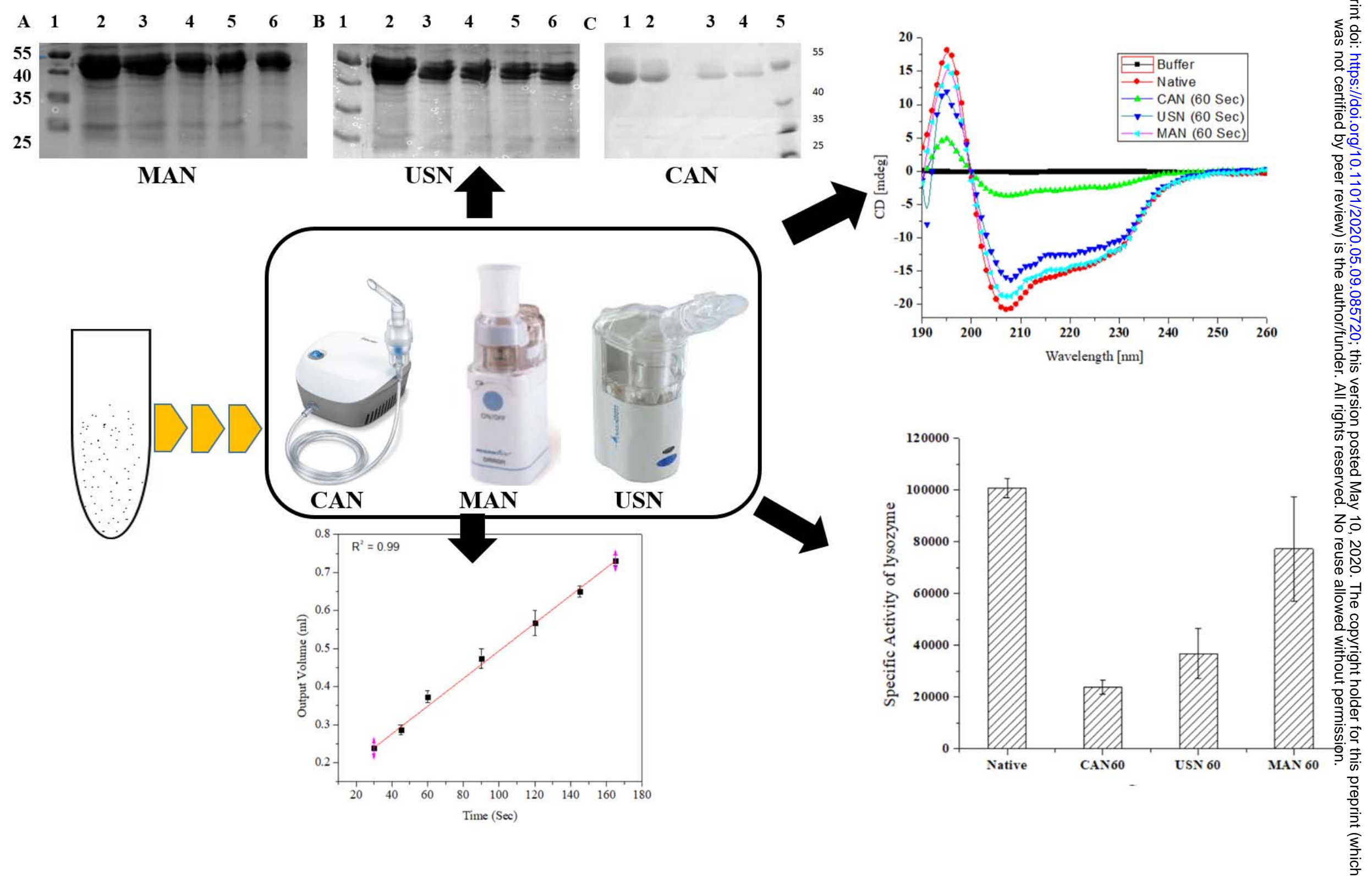

